\title{
Governance for global stewardship: can private certification move beyond commodification in fostering sustainability transformations?
}

\author{
Agni Kalfagianni ${ }^{1} \cdot$ Lena Partzsch $^{2} \cdot$ Miriam Beulting $^{2}$
}

Accepted: 29 June 2019 / Published online: 5 July 2019

(c) The Author(s) 2019

\begin{abstract}
Stewardship - the caring for fellow human beings as well as the nonhuman world—is receiving increasing attention from scholars in the field of global environmental change. Recent publications underscore that stewardship is becoming a key norm within the global international system of states, but that in remaining state-centric, stewardship fails to create a deeper systemic transformation of the international system's normative structure. In this article, we examine whether stewardship also underpins hybrid governance arrangements, which are a combination of public requirements and private standards, with a specific emphasis on certification. We argue that a stewardship ethos requires citizenship, compassion and sufficiency. We, thus, contribute to the burgeoning literature on certification by focusing on normative principles that are fundamental for sustainability governance, but have so far been neglected in governance research. Empirically, we are able to reveal broader implications of the normative transformations underway in global sustainability governance. To add depth to our analysis, we concentrate on palm oil, an agricultural commodity, which serves for food purposes and as a substitute for fossil fuels to mitigate global warming. Palm oil is representative of the interlinkages between social and environmental objectives, which are at the core of the notion of stewardship as conceptualized in this article. We find that stewardship underpins hybrid governance arrangements but momentarily it is realized only in niches. We argue that in order to move to a state of global stewardship, we need a bolder public policy agenda which respects environmental limits, acknowledges boundaries for the global poor, and allows for the expression of emotions in public dialogue.
\end{abstract}

Keywords Hybrid governance $\cdot$ Palm oil $\cdot$ Private certification $\cdot$ Stewardship $\cdot$ Sustainable development

$\begin{array}{ll}\text { Abbreviations } \\ \mathrm{CO}_{2} & \text { Carbon dioxide } \\ \mathrm{EU} & \text { European Union } \\ \text { FONAP } & \text { Forum on Sustainable Palm Oil } \\ \text { GDP } & \text { Gross domestic product } \\ \text { GHG } & \text { Greenhouse gas } \\ \text { GMOs } & \text { Genetically modified organisms } \\ \text { HIH } & \text { Hand-in-Hand }\end{array}$

Agni Kalfagianni

a.kalfagianni@uu.nl

Lena Partzsch

lena.partzsch@ifp.uni-freiburg.de

Miriam Beulting

miriambeulting@gmail.com

1 Copernicus Institute of Sustainable Development, Utrecht University, Vening Meineszgebouw A, Princetonlaan 8A, 3585 CB Utrecht, The Netherlands

2 Chair Group of Sustainability Governance, University of Freiburg, Tennenbacher Str. 4, 79106 Freiburg, Germany
IFOAM International Federation of Organic Agriculture Movements

ILUC Indirect land-use change

NGOs Non-governmental organisations

RED Renewable Energy Directive

RSPO Roundtable on Sustainable Palm Oil

USDA US Department of Agriculture

\section{Introduction}

The concept of stewardship, that is, the caring for fellow human beings as well as the rest of the planet, is receiving increasing attention from scholars in the field of global environmental change (Chapin et al. 2011; Steffen et al. 2011; Folke et al. 2016). These scholars argue that in an era where we are crossing critical planetary boundaries as a result of human action (Rockström et al. 2009), stewardship is important to underline the deep interconnections between humans and the biosphere and dignity among human relations. In 
this context, recent publications, from a political science perspective, underline that stewardship is becoming a key norm in the global international system of states (Falkner 2012; Palmujoki 2013; Buzan 2014; Falkner and Buzan 2019). Focusing particularly on the environmental dimension, these publications note that even though it remains incomplete, stewardship is now a key source of solidarist interaction among states. This is evidenced, they argue, by the growth of multilateral environmental agreements, the rise of diplomacy around sustainability concerns, and a general greening of state practices. In remaining state-centric, however, scholars observe that stewardship has failed to create a deeper systemic transformation of the international system's normative structure (Eckersley 2004; Falkner and Buzan 2019).

In this article, we examine whether stewardship also underpins hybrid governance arrangements, i.e. a combination of public requirements and private standards, with a specific emphasis on certification (Ponte and Daugbjerg 2015). With the trend towards commodification in the past 20 years, these arrangements have proliferated in a number of policy domains, from food and agriculture to marine fisheries and renewable energy, to name a few (Fuchs et al. 2011; Green 2013). Some of these arrangements even have stewardship in their names, for example, the Forest Stewardship Council and the Marine Stewardship Council (Auld and Gulbrandsen 2010), even though they hardly articulate what it means. This paper analyzes the extent to which stewardship is endorsed by non-state actors through the market, not only in name but also in practice. By doing so, we are able to draw broader conclusions regarding the normative transformations underway in global sustainability governance.

To add depth to our analysis, we concentrate on palm oil, an agricultural commodity for which hybrid governance arrangements exist with respect to food purposes as well as to palm oil substituting for fossil fuels to mitigate global climate change. We focus on the EU hybrid governance systems that uniquely exist for both organic and sustainable certification. The EU Organic Regulation promotes voluntary private standards for palm oil-based foodstuff. The EU Renewable Energy Directive (RED) makes certification of palm oil de facto mandatory for fuel substitution in the transport sector. ${ }^{1}$ The import and use of this commodity is especially contested (Kemper and Partzsch 2018; Stattman et al. 2018). Besides, palm oil is an important

\footnotetext{
${ }^{1}$ In December 2018, the EU adopted the revised Renewable Energy Directive (RED II) and the member states need to have it completely implemented by 30 June 2021 . The EU continues the promotion of palm oil-based biodiesel, but there are new limits for biofuels risking indirect land-use change (ILUC). Certification initiatives now need to revise their standards to reduce ILUC-risks.
}

commodity for this analysis because it represents the interlinkages between social and environmental objectives, which are at the core of the notion of stewardship as conceptualized above (Cassman and Liska 2007; Escobar et al. 2009; Ewing and Msangi 2009). More specifically, biofuels are considered important for reducing the dependency on fossil fuels and emissions from transport by, for example, the European Commission (2007). In this context, hybrid governance arrangements in the form of certification may provide environmental sustainability by guaranteeing that greenhouse gas (GHG) savings are not counteracted by an increase in the same emissions during the production and transformation of biomass. In particular, deforestation and indirect land-use change (ILUC), which occurs when biofuel cropland displaces other cropland, has been shown to substantially increase GHG emissions for many biofuels (Bourguignon 2015). Simultaneously, biofuels have been criticized for rising food prices, reducing the availability of land that could be used for food purposes, and raising land grabbing concerns, particularly in the Global South (Partzsch 2011; Levidow 2013). In this regard, certification would also need to consider aspects of social justice in order to foster stewardship. In this context, we ask two main questions:

- Acknowledging that hybrid governance arrangements entail commodification, to what extent are they also capable of fostering stewardship?

- What would it take to move to a stage of global stewardship, thus fostering both environmental sustainability and social justice, and what is the role of hybrid governance arrangements therein?

Below we first discuss trends of commodification, which have proliferated in hybrid governance arrangements in the form of certification. Commodification, we argue, represents an ethos of individualism, convenience and efficiency, which tends to ignore trade-offs or subjects any reconciliation between environmental and social objectives to a utilitarian logic of cost-benefit calculations. That way it remains an inadequate response for sustainability transformations. We then contend that a stewardship ethos of citizenship, compassion and sufficiency has the potential to reconcile environmental sustainability and social justice and thus foster a more comprehensive and transformative sustainability agenda.

Accordingly, we delineate principles of stewardship as analytical heuristics to evaluate palm oil certification. Based on these principles, we explore EU hybrid governance arrangements and respective certification schemes in the two fields of palm oil for organic foodstuff and sustainable biofuels. While the certification of organic foodstuff is completely voluntary, the certification of palm oil-based 
biodiesel is de facto mandatory in the EU. After presenting our results for each sector separately, we finally discuss the differences between the two sectors and outline the broader implications of our analysis.

The paper demonstrates that stewardship is possible despite commodification, but we find it to be realized only in niches. This is particularly evident in palm oil certification for food purposes, which despite, or although, being profoundly based on consumerism and individual choice, it allows for greater environmental sustainability and social justice on a case-by-case basis. In contrast, biofuel certification, while it is de facto mandatory in the EU, is severely constrained as it lacks any notion of sufficiency. We argue that in order to move to a state of global stewardship, we need a bolder public policy agenda which respects environmental limits, acknowledges boundaries for the global poor, and allows for the expression of emotions in public dialogue.

\section{Commodification in sustainability governance}

In 1944, in his book The Great Transformation, Polanyi (2001) noted the emergence of an entirely novel relation between markets and society on the basis of the market economy. While in the nineteenth century markets and regulation co-evolved, the market economy is "self-regulating". It is "controlled, regulated and directed by market prices", and rests on the expectation that "human beings behave in such a way as to achieve maximum economic gain" (Polanyi 2001). A market economy is thus governed by supply and demand, instead of governmental regulation. Importantly, all inputs of production, including labor, land and money, are to be traded in the market. Polanyi (2001) called these "fictitious commodities" in that they are not originally produced for sale on the market. The creation of "fictitious commodities" ultimately turns into an organizing principle for the whole of society - that is, institutional arrangements only allow the market to function on the basis of this "fiction"- resulting in societies themselves becoming commodified. In turn, such societies will only foster environmental and social goals to the extent that they serve utilitarian objectives.

There is an extensive literature today that views hybrid governance arrangements as mechanisms of commodification (e.g. Guthman 2007; Higgins et al. 2015; Setyowati and Mcdermott 2017). This literature highlights the limits of commodification and-as we argue below-of the three main principles that support it namely, consumerism (priority of consumption choices), convenience (easily accessible alternatives) and efficiency (the least possible cost). When these become guiding governance principles, any trade-offs tend to prioritize actions that oversimplify complex relationships and processes through efforts to monetize them (Liodakis 2010; Kopnina 2017), potentially failing to ensure environmental sustainability and social justice.

\section{Consumerism}

Consumerism rests on the assumption that enlightened consumer choices will ultimately lead to a better world in the form of ethically-responsible planning and management of resources (Chouliaraki 2013). For example, if consumers buy palm oil that is certified as originating from a sustainably-managed plantation they are contributing to addressing environmental and social pressures on producing regions and also on a global scale (e.g. reducing deforestation, climate change). Often more significantly, if governments and intergovernmental organizations procure on the basis of private standards, public consumption also contributes towards alleviating sustainability challenges (Gulbrandsen 2014). However, although better and conscientious consumption carries promise (see e.g. Meyer 2015), scholars have raised three major points of concern.

First, consumption as an act for fostering environmental sustainability and social justice centers around the self (Chouliaraki 2013). It satisfies and empowers the individual who experiences a "feel good" moment of gratification through the simple act of consumption. The individual can continue a guilt-free life, without critically reflecting on the deeper causes of unsustainability and injustice (Gunderson 2014). Thus, while the neoliberal subject has the possibility for self-expression via the choice of particular "ethical" commodities, she remains constrained by expressing her will predominantly through market institutions that create and reproduce a public that becomes "narcissistic" (Gunderson 2014) in pursuing the public good on the basis of personal satisfaction.

Second, consumption opportunities appear to be majorly stratified. The richest $20 \%$ of humanity account for $76.6 \%$ of the world's total private consumption. In contrast, the poorest $20 \%$ account for just $1.5 \%$ of global consumption (Chen and Ravallion 2008; Biermann 2014). While developing countries, particularly China and India, both have a growing consumer class, this is still comparatively low in relation to their total population. Specifically, the Worldwatch Institute (2018) reports that China and India's consumer sets constitute only $16 \%$ of the region's population, whereas in Europe the figure is $89 \%$. Likewise, the $12 \%$ of the world's population that lives in Western countries accounts for $60 \%$ of total private consumption spending, while the about $33 \%$ of the world's population living in South Asia and sub-Saharan Africa accounts for only 3.2\%. Sachs and Santarius (2007) 
speak of the "triad of omnivores", i.e. North America, Europe and Japan, consuming resources beyond their fair share.

Third, better consumption is not equivalent to less consumption. Indeed, numerous studies emphasize the need to reduce overall consumption and waste, instead of simply shifting to a different set of products (Jackson 2009; Lorek and Fuchs 2013). For example, an increasing number of Western consumers buying " $\mathrm{CO}_{2}$-free" products does not outbalance the overall increase of GHG emissions from continuous growth in worldwide consumption. As Western lifestyles spread around the world, sustainable consumption can hardly be considered an appropriate course of action on its own.

\section{Convenience}

The concept of convenience rests on the premise that privileged individuals and societies can continue to live more or less undisrupted. The principle implies that simple actions matter. At the individual level, the examples are plentiful: collecting plastic lids to provide for the disabled while also contributing to recycling (e.g. Caps of Love and Caps for a Cause in the US); playing an online game to deliver rice to the hungry (e.g. Freerice.com); driving an electric car to reduce air pollution in cities (e.g. subsidies for electric vehicles in the Netherlands); buying a certified product at a large supermarket chain. At the collective level, firms are encouraged to adopt private standards and certification schemes to demonstrate commitment to sustainability efforts in relation to fulfilling obligations created by states, for example, through public procurement policies (Gulbrandsen 2014).

Convenience is a strong argument in favor of the diffusion of sustainability practices. It encourages people to adjust their habits to more sustainable and just behaviors by overcoming the intention-action problem. Indeed, sustainability will most likely only reach a wider public if sustainable practices are easy to adopt. However, convenience as an overarching principle of sustainability governance has significant limitations. First, like consumerism, convenience is stratified. Research shows that poorer and otherwise marginalized communities face larger constraints in accessing sustainable products in relation to wealthy communities (Alkon and Agyeman 2011). Second, sustainability may require changes that are beyond the sphere of convenience. Many of the environmental and social changes we are experiencing require radical transformations. In this context, governance arrangements that fail to encourage disruptive practices and simply reproduce the dominant social structures on the basis of convenience are likely to fall short in achieving sustainability (Gunderson 2014).

\section{Efficiency}

Efficiency has its origins in modernity (Princen 2005). Efficiency, according to the Cambridge dictionary, refers to the good use of time and energy in a way that does not waste any. Two developments equated efficiency with progress, and rendered it the fundamental organizing principle for society during the period of 1890-1930: First, economists invented the notion of the "economic man", portraying humans as consistently rational and narrowly self-interested agents. Second, corporations became dominant business actors who emphasize efficiency gains by reducing transaction costs and information asymmetries. In the sustainability domain, corporations claim to set the "right price" for market products by internalizing the environmental and social costs of unsustainable practices (Gómez-Baggethun and Muradian 2015).

While it is hard to argue against efficiency, it does have some major constraints in terms of its pedestal status. Indeed, in its modern use, efficiency is a quantitative measure of how a task is performed following a cost-benefit ratio generally independent from quality considerations (Princen 2005). Yet, there is a long history of environmental failures and unintended side effects resulting from giving priority to efficiency (Princen 2005). Examples include the advancement of industrialized agriculture, the widespread use of motorized vehicles, the extensive use of airplanes as a means of international travel, and so on. Efficiency is also embodied in the contemporary discourse of smartness as a means to promote environmental sustainability and social justice in various fields, including, most prominently, agriculture (e.g. biotechnology) and urban environments (e.g. smart cities). However, the social gains from efficiency are also contested in this context, particularly when these occur at the expense of marginalized communities, countries or regions (Potts et al. 2014).

\section{Beyond commodification: concept and principles of stewardship}

Stewardship, as we argue below, encompasses the principles of citizenship, compassion, and sufficiency (see Table 1). Stewardship has its origins in Christianity, in which it encourages humble simplicity and ascetism, humility before the whole, and respect towards other people and nature (Chryssavgis 2007). In recent years, there has been increasing attention paid to the notion of stewardship as a guiding concept for sustainable development (Chapin et al. 2011; Steffen et al. 2011; Folke et al. 2016). Sustainable development is concerned with the ethics of planning and 
management of resources in a way that allows "development [to meet] the needs of the present without compromising the ability of future generations to meet their own needs" (United Nations General Assembly 1987). In this context, we argue that stewardship, caring for and safeguarding Earth's ecological systems as well as human society, is a key norm for reconciling environmental and social objectives in sustainability governance. Table 1 provides an overview of the three stewardship principles. It also includes the analytical questions, which we derive from the literature in this section and apply to palm oil certifications in the next section.

\section{Citizenship}

A wide range of scholars from different perspectives and disciplines underline the importance of citizenship for sustainable transformations (Bäckstrand et al. 2010; O'Neill 2001). The concept of citizenship is associated with a person's membership to a collective and the associated duties and responsibilities that derive from that. Citizenship is not necessarily constrained within a territorial space but has a globalizing character (e.g. Rygiel 2010; Squire 2010), particularly when it concerns sustainability issues. Drawing on the burgeoning literature on environmental and ecological citizenship (e.g. Dobson and Sáiz 2005; Dobson and Bell 2006) as well as political economy approaches on structural conditions that enable or hinder political participation (e.g. Fuchs 2007) we highlight four critical components for a stewardship approach to citizenship in hybrid governance.

First, citizenship demands a link between the personal and the collective level of action (see Table 1). Citizenship is broadly informed by the idea that what is good for an individual may not necessarily be good for the same individual as member of a collective (Smith 1998; Barry 1999; Dobson 2007). Rather citizenship requires commitment to the common good (Dobson 2007). Unlike consumerism, which as we argued above, centers around the self, citizenship demands a political space where people can organize collectively to regulate or transform some aspect of their shared social conditions. This space also allows for communicative activities in which people can try to persuade one another to join in transformative collective action (Young 2004). A key criterion for examining citizenship in hybrid governance arrangements, then, is whether they create a global political space that allows for the exposition, deliberation and contestation of different standpoints on the key sustainability issues that they aim to address.

Second, citizenship requires the realization and acceptance that some individuals and actor groups draw more on environmental resources and have unequal planetary impacts in relation to others. According to Dobson (2007) this realization is a matter of justice and not charity. Indeed, justice calls for the attribution of obligations because there are responsibilities attached to the suffering of others or the natural environment. Charity, on the other hand, is a weak basis for obligation easily withdrawn and reproducing the vulnerability of the recipient (Dobson 2007). In the analysis below we examine whether hybrid governance arrangements acknowledge inequalities in the relevant sustainability domain and attribute responsibilities and obligations accordingly.

Third, in relation to citizenship, recognizing who actually has the political autonomy to act as a citizen becomes crucial. To act as a citizen, one must have the ability to participate freely and equally in a political space. In this context, Fraser (2000) understands the act of recognition to be a matter of social status, that is, the status of different members of the public as partners in social interaction. According to Fraser, it is important to understand whether governance arrangements consider certain actors as inferior and others as superior or misrecognize particular actors by denying them the status of full partnership in a social interaction. Fraser's perspective on the politics of recognition departs from the more traditional notion that suggests recognition is related to difference in identity. Recognition is an important act of citizenship because it is a requirement for political participation and voice (see also Schlosberg 2004). To evaluate citizenship in hybrid governance arrangements, then, we also need to examine whom they recognize as participants in the political process and whom not. In other words: Do governance arrangements constitute certain actors as inferior and others as superior?

Fourth, the creation of conditions necessary for political participation and voice is pivotal for citizenship. This is especially important in view of global power inequalities and resource differences. Business actors, in particular, have been increasing their power vis-à-vis states and civil society by controlling significant segments of the global market and by creating scarce and competitive environments for investment opportunities by governments, thus generating dependencies (Fuchs 2007). For example, Steen Jacobson, a chief economist of the Saxon Bank, highlighted the continuous rise of corporate profits, which were the highest ever in history in the US in 2016, over a simultaneous decline of overall employment compensation in relation to GDP (Shedlock 2016). Confronted with such material differences and respective inequalities among actors, we can therefore study below whether citizenship in hybrid governance strives for leveling the playing field.

\section{Compassion}

Citizenship alone may not be a sufficient condition to foster stewardship, as providing the opportunity and space 
for political participation does not automatically lead to environmental sustainability and social justice. Blühdorn (2013), for instance, challenges participatory and decentralized forms of governance more broadly by arguing that they promote what he terms the "governance of unsustainability". This is because, while these governance arrangements appear to offer voice and participation, in practice they try to balance two conflicting tendencies: (1) the satisfaction of demands for democratic citizenship and (2) the simultaneous satisfaction of non-democratic needs (in particular, freedom to consume). Accordingly, citizenship needs to be accompanied by compassion.

According to political philosopher Nussbaum (2015) the good requires effort and sacrifice. The "good" as understood by Nussbaum includes a wide range of goals including health, education, political rights and liberties, environmental quality, and more. Only actions that are costly, though not necessarily only in terms of money, can make us appreciate that something matters. In this context, observations from the neighbouring field of humanitarianism that we are currently moving away from strong emotions towards a short-term and low-intensity form of agency, which is no longer inspired by an intellectual agenda but momentarily engages us in practices of playful consumerism (Chouliaraki 2010) are extremely pertinent for sustainability governance as well.

Instead what we need is strong political emotions. A relevant emotion in support of stewardship is compassion, "a painful emotion directed at the serious suffering of another creature or creatures" (Nussbaum 2015, p. 142). Although this discussion is mostly directed towards fellow human beings, there is no ontological constraint in extending it to non-human entities as well. Compassion according to Nussbaum has three thoughts as central parts. First, a thought of seriousness in that the person who feels compassion thinks that someone else is suffering in some way that is important and not trivial. Second, a thought of non-fault in that the other person is not to blame for their situation. And, third, a thought of similar possibilities in that the suffering person is similar to the person who feels the emotion and has similar possibilities in life. However, this last thought is not a necessary condition for compassion as we also feel compassion for animals.

Nussbaum adds to that list a fourth thought, an eudaimonistic one, that places the suffering person among the important parts of the life of the person who feels the emotion. She argues that the things that elicit a strong emotion in us are things that correspond to what we have invested implicitly or explicitly with importance in our thoughts, about what we consider important in life. However, the thought of importance could only last temporarily and, therefore, that too does not always stimulate a compassionate response.
In this context, empathy, the ability to feel someone else's emotional state (Decety and Yoder 2016), is also relevant. Empathy requires not only knowledge of someone else's situation but the ability to enter into another's predicament. Although empathy is necessary it is not a sufficient condition for compassion. Thus, we may be able to empathize with someone but feel superior rather than compassionate towards them. People may even derive pleasure by being able to enter someone else's suffering, for instance, when they are sadists. Despite its limitations, as Nussbaum reminds us empathy is helpful for compassion because it requires recognizing the other and their suffering.

Compassion, then, is necessary for stewardship. Without compassion we lack both the affinity with the subject and the willingness to act in a meaningful way. However, although human beings are capable of compassion institutions need to be able to sustain and broaden it. Psychological experiments show, in that respect, that a focus only on the technical aspects of a particular situation weakens emotions whereas an imaginatively participation in someone else's experience strengthens it (Batson 2011).

In order to evaluate hybrid governance arrangements in terms of compassion we focus on four main questions. First, how are people, places and the environment depicted through communication channels (for example, the website and other documentation)? For example, we are interested in whether people are depicted as human beings with dignity and rights or whether they are rather perceived as the recipients, those who gain, but do not have an equal status with the actors participating in the governance structure. Second, we are interested in whether relationships are presented as reciprocal in the form of mutual need and interdependence or unilateral, from the benefactor to the community or the natural environment: Are there efforts to communicate a thought of seriousness, i.e. that someone else is suffering in non-trivial way? Third, are there efforts to communicate a thought of non-fault, i.e. that other persons are not to blame for their situation nor are they victims of it? And, finally, are there efforts to communicate a thought of similar possibilities, i.e. that the suffering person is similar to the person who feels the emotion and has similar possibilities in life? Examining communication that way will enable us to understand whether it is used to generate "pity" (Chouliaraki 2010) or foster compassion.

\section{Sufficiency}

Finally, sufficiency is key for stewardship. At the individual level, sufficiency is understood as reducing consumption and enacting lifestyle changes with the aim of fostering environmental sustainability (Alcott 2008). Like compassion, sufficiency is something human beings are capable of, but it can be challenging to implement. For 
example, one knows when they are satiated with food and when they have had enough. However, it may take a considerable amount of self-control in order to stop oneself from overindulgence.

At the collective level, sufficiency requires decision makers to consider when too much resource use or too little regeneration jeopardizes important values, such as ecological integrity and social cohesion (Princen 2005). It is the opposite of greed, overindulgence, and excess. Sufficiency at the collective level would require refraining from economic activity that depletes an environmental resource more than necessary, even if doing so would bring additional profit. In this context, sufficiency sets maximum (upper-bound) thresholds for the rich, while also respecting the lower-bound for the poor (Parks 2012; Heindl and Kanschik 2016).

The adoption of a sufficiency principle can have radical implications for sustainability governance arrangements. While some scholars argue that sufficiency can be incorporated within established structures and institutions (e.g. through taxation) (Heindl and Kanschik 2016), others argue in favor of rethinking the entire framing of sustainability governance instead of focusing on particular policy instruments (Muller and Huppenbauer 2016). In our analysis below, we will explore whether hybrid sustainability governance can incorporate sufficiency as the third central principle of stewardship in addition to citizenship and compassion: Is there a maximum (upper bound) thresholds for the rich? Is there respect for the lower bound for the poor?

Methodologically, we use the questions derived in this section to analyze hybrid governance arrangements for palm oil certification. Our analytical framework consists of three stewardship principles with several criteria and sub-questions, respectively (see first column of Table 1). We focus on the EU regulative context and a "best practice" certification case in each field. In both fields, the EU adopted regulations require non-state certification, including the certification of palm oil in third (non-EU member) countries, such as Ghana and Indonesia. The EU Organic Regulation defines how agricultural products and foods that are certified as organic products have to be grown. The Renewable Energy Directive requires all biofuels contributing to the EU renewable energy targets, including palm oil-based biodiesel, to be certified as sustainable. We coded the two EU policy documents and a wide range of the certification initiatives' documents (certification standards, websites, press releases etc.) on the basis of Table 1.
Moreover, we used transcripts of a total of 12 semi-structured interviews, ${ }^{2}$ which we conducted with public actors, companies and NGOs. Four of the semi-structured interviews, which we used for this article, were conducted in September and October 2017. Three of the interviewees represented stakeholders involved in the two certification initiatives; the fourth interviewee represented a NGO advocating for an EU palm oil boycott. In this period, we also participated in the annual meeting of the Forum on Sustainable Palm Oil (FONAP) in Berlin on September 27, 2017. An additional interview was possible with Rapunzel in Legau, but we were not allowed to cite from it in this article without explicit permission. Therefore, we used published interviews as part of our document analysis.

The FONAP meeting gathered actors involved in certification of palm oil for both food and biofuel purposes, particularly from the EU with only a few from palm oil exporting countries of the Global South. Because of this imbalanced representation, we complemented our empirical data collection with a field trip to Indonesia in August and September 2018. There, we met with local researchers and conducted additional interviews in Bali, Bogor and Jakarta. Some of the researchers and NGOs who we met were very skeptical of private certification. We used eight of our interview transcripts for this article. These transcripts result from interviews with public actors, a palm oil industry representative, and international and local NGOs. The interviews helped to clarify the initiatives' stances and their performance regarding stewardship, and the interviews bolstered the results of our document analysis. For the content analysis of both the documents and the interviews, we used a manual coding process guided by Table 1 . It is necessary to maintain interviewee anonymity against the backdrop of ongoing negotiations for the RED II implementation. References to the documents that we used are provided and most of them are available online.

While trying to be comprehensive in terms of covering an array of different perspectives, our analysis here is also limited especially in its focus on two 'best practice' cases regarding food and biofuel certification for palm oil. Future research needs to extend to a wider range of hybrid governance arrangements in order to produce more nuanced results. Below we present our analysis first with respect to hybrid governance arrangements on palm oil certified for food and next for biofuels.

\footnotetext{
2 These interviews were part of a larger project on private certification in which two of the authors were involved and in which more than 60 interviews were conducted.
} 


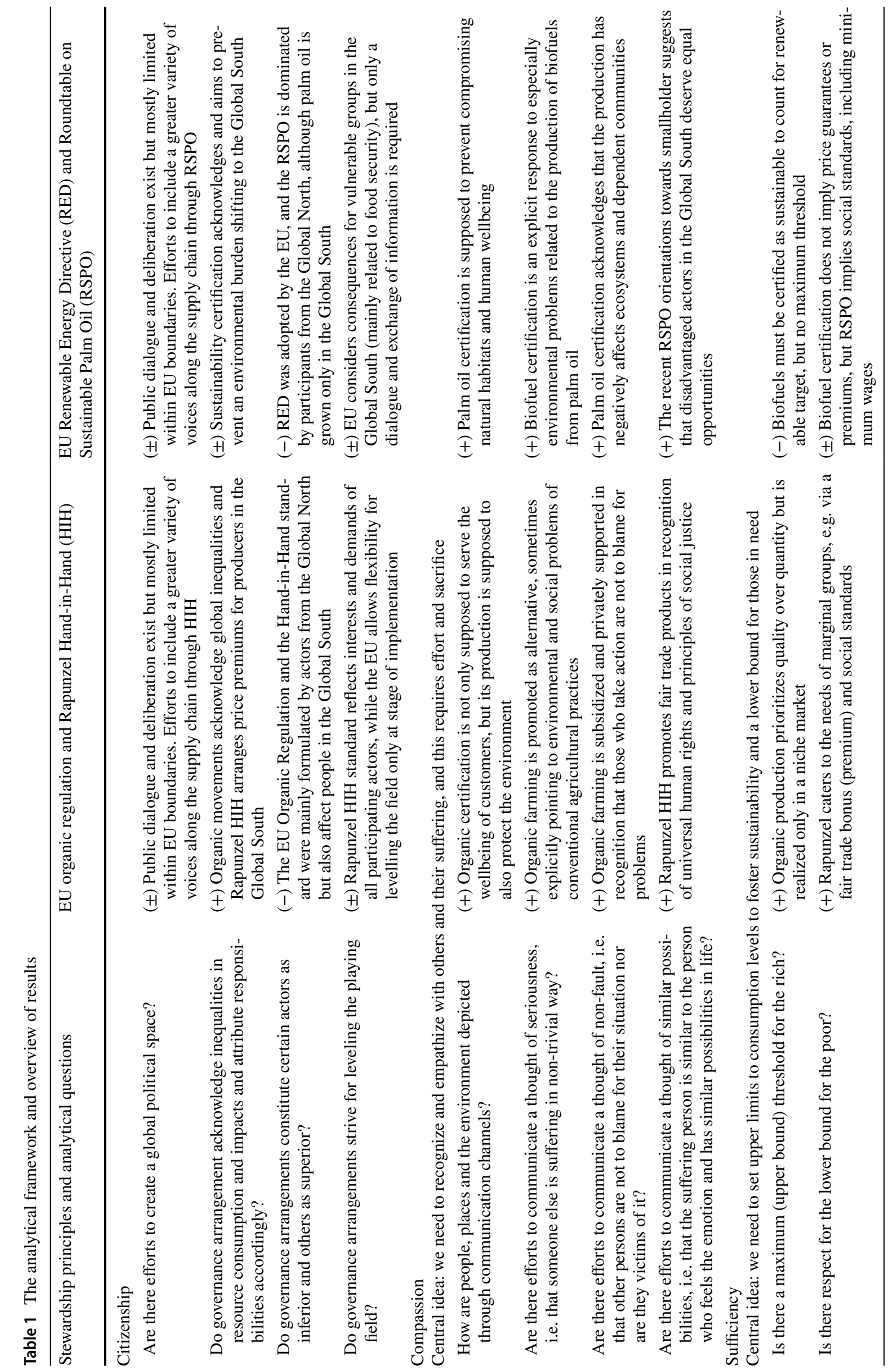


Fig. 1 Food labels (selection)

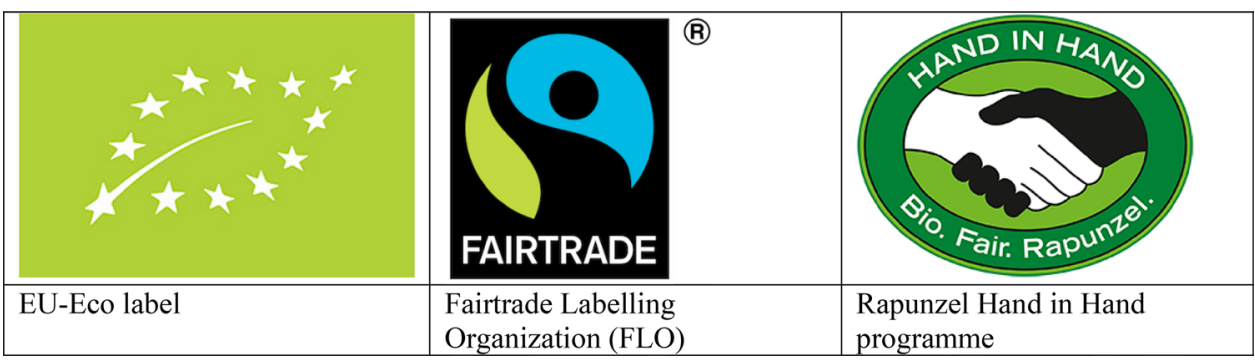

Textbox 1 Food certification: Rapunzel Hand-in-Hand (HIH) sustainability standard for palm oil
No clear-cutting of primary forests; protection of the natural habitat of endangered animals and plants
Promotion of animal and plant diversity also inside palm plantations
$100 \%$ organic cultivation, no combined organic-conventional operations and absolute prohibition of geneti-
cally modified organisms (GMOs)
Integration in locally grown structures, respect of land ownership rights and rights of indigenous people
Transparent production structures and process chains
Regular on-site visits of Rapunzel agri-engineers
Verifiable social standards
External control and certification of independent agencies

Source Rapunzel (2019), authors' translation from German

\section{Palm oil certification for food purposes: realizing stewardship in ethical niches}

The EU adopted the Organic Regulation (EC no. 834/2007) in 2007. The US Department of Agriculture (USDA) Organic is the equivalent in the United States. Both EU and USDA Organic belong to the International Federation of Organic Agriculture Movements (IFOAM) Family of Standards. Farmers are required to maintain and replenish soil fertility without the use of toxic, persistent pesticides and fertilizers. In addition, organic production relies on adequate animal husbandry and excludes the use of genetically modified organisms (GMOs) (IFOAM 2019). Compliance is enforced by public authority. Simultaneously, however, this hybrid governance arrangement fundamentally relies on commodification principles, in particular, the principle of consumerism, as the (enlightened) individual consumer is the key player. Opportunities for farmers depend on the consumers' voluntary commitment to pay higher prices for organic certified products.

In line with the principle of convenience, consumers can continue their lives undisrupted by simply buying certified products. Finally, with regard to the principle of efficiency, having a unified labeling system (the green leaf, see Fig. 1) was seen as a precondition for a functioning market, reducing transactions costs, and overcoming information asymmetries, as well as internalizing the environmental and social costs of unsustainable practices. However, the Organic Regulation defines only minimum requirements for certifying products as organic, and many certification initiatives voluntarily commit to more ambitious standards. One of the most ambitious efforts in complementing organic with fair trade principles is the Rapunzel Hand-in-Hand (HIH) program (see Textbox 1) and was therefore chosen as an illustrative case study for our analysis. Rapunzel was founded in Augsburg, Germany, in 1974 by Joseph Wilhelm and Jennifer Vermeulen. They started the Hand-in-Hand (HIH) initiative in 1992 with the aim to be "fair to people and fair to nature" (Rapunzel 2019).

In the following sections, we present our results on the potential of hybrid governance around the EU Organic Regulation to promote stewardship through voluntary private standards. When presenting our results, we answer each question raised in the theoretical framework above. In Table 1, the second column summarizes our results.

\section{Citizenship and palm oil certification for food purposes}

The first principle of stewardship is citizenship, and we defined four criteria for examining it in hybrid governance arrangements. First, we examined whether such an arrangement creates a global political space. The EU Organic Regulation alone does not foster the development 
of a global political space. The Regulation requires that organic-certified products must comply with the EU organic standards to be sold on the EU market, irrespective of whether they are produced within or outside EU member states (European Commission 2007). However, although interests of third countries are taken into account, the political space of deliberation and co-decision is limited to EU boundaries. This is not necessarily different when it comes to HIH. Regarding palm oil, in particular, the 2016 Legau Declaration urging policy makers to move beyond voluntary commitment when it comes to the fairness and sustainability of palm oil was signed in the context of FONAP which brings together a variety of supply chain actors, scientists and civil society organizations (Rapunzel 2019), but almost exclusively with a basis in the Global North.

Second, citizenship requires the recognition of inequalities among individuals and actor groups. Our analysis reveals that HIH acknowledges global inequalities. "A healthier and fairer world was our big vision", said founder Wilhelm about their initial motivation. ${ }^{3}$ Like other fair trade programs, HIH arranges price premiums for producers in the Global South to enable them to participate in organic agriculture (Rapunzel 2019). However, third, in terms of realizing citizenship, it is crucial who actually has the political autonomy to participate in hybrid governance arrangements and ethical consumption. For example, state-led regulation like the EU Organic Regulation is formulated and adopted only by (European) state actors (European Commission 2007; Rapunzel 2018). In contrast, HIH argues that the standard and criteria (see Textbox 1) are developed together with affected people, and that interests and demands of all participating actors are taken into account (Rapunzel 2014, 2018).

Fourth, regarding the creation of conditions necessary for political participation, there are varying levels of ambition. EU Organic, for instance, mentions the need to leveling the field but this affects only the stage of implementation (European Commission 2007). HIH through its fair trade focus aims by definition to improve the living circumstances of those in need (Rapunzel 2019). However, while this may lead to economic empowerment it does not necessarily translate to empowerment for political participation. Fair trade has faced criticisms in this regard particularly because its commercialization through the involvement of large corporate buyers has raised concerns for the strengthening of commodification and erosion of civic engagement (Jaffee and Howard 2010; Daviron and Vagneron 2011). Although these criticisms are recognized in the literature, scholars point out that overall fair trade is still largely based on mission-driven organizations that promote relational and civic values based

\footnotetext{
3 Original quote in German: "Eine gesündere und gerechtere Welt war unsere große Vorstellung" (Rapunzel 2014, p. 2).
}

on both personal commitment and collective responsibility (Raynolds 2012; Partzsch et al. 2019).

\section{Compassion and palm oil certification for food purposes}

For hybrid governance to provide stewardship, citizenship needs to be accompanied by compassion. Again, we defined four criteria defining this principle. Regarding our first criterion of how people, places and the environment are depicted through communication channels, we found that organic governance arrangements emphasize that organic products are not only supposed to serve "the wellbeing of the customers" (Rapunzel 2014, p. 2); organic production is also supposed to protect and support the environment (Rapunzel 2014; IFOAM 2019). This illustrates compassion in the sense of recognizing and empathizing with others species and their suffering from environmental degradation. Second, we found that organic farming is promoted as an alternative, sometimes explicitly pointing to environmental and social problems of conventional agricultural practices that make ecosystems and people suffer in a non-trivial way (Chevriot 1972; IFOAM 2012; Rapunzel 2014).

Third, there is recognition that other persons are not to blame for their situation (Rapunzel 2014, 2018, pp. 15-18). Evidence for this is that organic farming is subsidized and privately supported in recognition that those who take action are not to blame (European Commission 2014; Rapunzel 2014, 2018, pp. 15-18). In an illustrative visual, the label of Rapunzel HIH shows a handshake of a black and white hand, likely aiming to evoke feelings of a reciprocal relationship among actors in transnational supply chains (see Fig. 1). At the occasion of Rapunzel's 40th anniversary in 2014, HIH founder Wilhelm noted that he is proud of not having founded Rapunzel out of "ego motives" (Rapunzel 2014, p. 2); in contrast, his aim was to radically change own living circumstances in order to create "a healthier and fairer world" (Rapunzel 2014, p. 2). There is a thought of seriousness in the sense of actors in organic governance arrangements understand that environmental and social concerns are interconnected and that both natural environment and people are seriously suffering from industrial agriculture (IFOAM 2019; Rapunzel 2019). Finally, fourth, there are efforts among organic governance arrangements to communicate a thought of similar possibilities. In this context, HIH promotes fair trade products in recognition of universal human rights and principles of social justice (Rapunzel 2019).

\section{Sufficiency and palm oil certification for food purposes}

Finally, the principle of sufficiency refers to the need to limit the consumption of the wealthy parts of the global society, 
Textbox 2 Best practices: the Roundtable on Sustainable Palm Oil

\author{
Impact goal: prosperity: competitive, resilient and sustainable sector \\ Principle 1. Behave ethically and transparently \\ Principle 2. Operate legally and respect rights \\ Principle 3. Optimise productivity, efficiency, positive impacts and resilience \\ Impact goal: people: sustainable livelihoods and poverty reduction \\ Principle 4. Respect community and human rights and deliver benefits \\ Principle 5. Support smallholder inclusion \\ Principle 6. Respect workers' rights and conditions \\ Impact goal: planet: conserved, protected and enhanced ecosystems that provide for the next generation \\ Principle 7. Protect, conserve and enhance ecosystems and the environment
}

Source RSPO (2018, p. 12) given the environmental boundaries of our planet as well as creating a lower bound for the world's poor. Organic production is based on sufficiency in that it prioritizes quality over quantity, even though there are no strict boundaries as to the amount of resources to be used for production and consumption (European Commission 2007; Rapunzel 2014).

In terms of creating a lower bound for the world's poor this is primarily taking place via price mechanisms. Specifically, the price of organic (and fair trade) palm oil far surpasses the world market price for conventional palm oil. The world market price of palm oil is 525 EUR per 1 ton (Börse 2018), compared to production costs of 2300 EUR per ton in the HIH Ghana project (Zero Palmöl 2018), as of June 2018. In the case of the HIH program, the product price is further increased, because Rapunzel pays a fair trade bonus (premium) to HIH partners and complies to a range of social standards (Rapunzel 2014, 2018). Moreover, fair trade implies price guarantees to farmers at the beginning of the season and this guarantee shields farmers against currency decline, among other risks. Rapunzel $\mathrm{HIH}$ recompensates farmers also for the loss of their harvest in case of force majeure, such as natural disasters (Rapunzel 2018, p. 20). However, organic palm oil has an extremely low market share of 37.687 MT in relation to other certification programs. For example, the market of the Roundtable on Sustainable Palm Oil (RSPO), which will be discussed later, is 8.184.201 MT (Potts et al. 2014). Limited market share is a general concern for organic products (Rapunzel 2014, p. 3). Finally, while organic food certification itself respects limits and thresholds, it is not clear whether consumers of certified products, who tend to be the more educated and affluent individuals (Kalfagianni and Fuchs 2011), have to actually alter their lifestyle choices, or whether they just pay a higher price while maintaining the same lifestyle.

In sum, the organic hybrid governance arrangements that we studied here overall demonstrate a stewardship ethos, especially, in terms of compassion with nature and other human beings. Citizenship is more problematic, however. On the one hand, organic movements acknowledge global injustices and try to incorporate the voices of different actors along the supply chain. On the other hand, standards are mainly formulated by actors from the Global North. Regarding sufficiency, organic production prioritizes quality over quantity while, however, depending largely on the voluntariness of more educated and affluent consumers and hence only realizing stewardship in ethical niches.

\section{Palm oil certification for biofuel purposes: citizenship and compassion without consideration of sufficiency}

In addition to organic governance arrangements that cover palm oil in respect to food purposes, there is also the EU Renewable Energy Directive (RED) (2009/28/EC) that regulates palm oil-based biodiesel, among other renewable energy sources. According to RED, $10 \%$ of all energy used in the European transport sector must come from renewable sources by 2020 . Biofuels, including palm oil-based biodiesel, are seen as instrumental in reaching this target

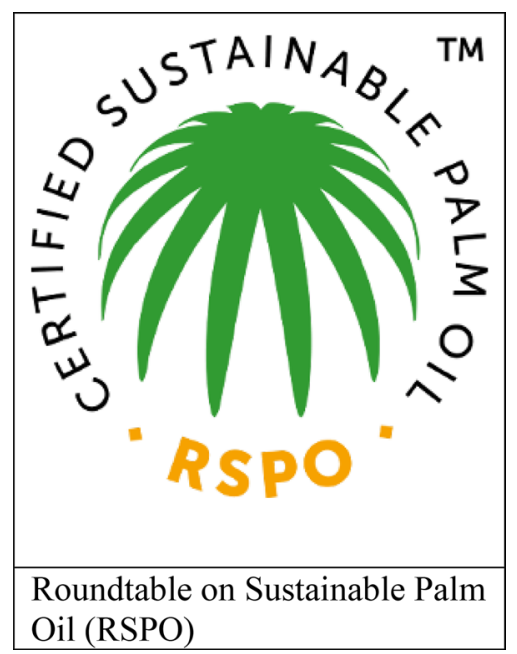

Fig. 2 Example of a palm oil label 
(European Commission 2009). Therefore, the share of palm oil used in Europe has been growing significantly. While only $8 \%$ of palm oil in Europe was used for biodiesel in 2010, this share grew to 45\% in 2014 (Dings 2016). However, biofuels only count for the renewable target, if they meet a range of sustainability criteria, and private certification allows producers to prove compliance with this 'metastandard' (Moser et al. 2014; Ponte and Daugbjerg 2015). As biofuels cannot yet be produced at a lower price than fossil fuels, it does not make sense to import biofuels, or ingredients such as palm oil, that do not comply with the metastandard. Certification has thus become de facto mandatory for palm oil used for biofuel purposes in the EU (Ponte and Daugbjerg 2015).

The Roundtable on Sustainable Palm Oil (RSPO) (see Textbox 2 and Fig. 2) is the most prominent-and a particularly ambitious example of an EU-accredited private certification scheme (Kemper and Partzsch 2018; Stattman et al. 2018). We therefore chose this program as an illustrative case to examine the stewardship potential of biofuel certification.

Unlike the EU Organic Regulation, RED is not based on the principle of consumerism, in the sense of targeting individual consumers. Car drivers do not choose certified fuel over non-certified one (Stattman et al. 2018). However, in line with the principle of convenience, consumers can continue their transport, more or less uninterruptedly, only based on (certified) renewable, instead of fossil sources (Stattman et al. 2018). Following the principle of efficiency, sustainability is supposedly achieved via regulation, certification and productivity gains (European Commission 2009). In the next sections, we assess if the biofuel hybrid approach fulfils three stewardship principles of citizenship, compassion and sufficiency. In Table 1, the third column summarizes the results.

\section{Citizenship and palm oil certification for fuel purposes}

Efforts to create a global political space-required by the first criterion of citizenship - are clearly visible in both RED and RSPO. For example, RED prescribes the meta-standard, irrespective of whether palm oil is produced inside or outside the EU (European Commission 2009). However, in contrast to the organic hybrid regime where the political space was created around organic movements, here there is a lack of grassroots origin. Rather EU member-states orchestrate a number of private national and transnational standards for the production and promotion of renewable energy in the EU. Among these standards, RSPO is a multistakeholder initiative that tries itself to create a global political space by bringing together palm oil supply chain actors and the world's largest palm oil regions (RSPO 2019). In this vein, a representative of an international NGO participating in the RSPO explained: "[W]e see the value in policy discussions (...). If possible, we want to coordinate with [the local government and with the local farmers]" (ST, interview 21 August 2018, Bali).

The second criterion of citizenship refers to the need to acknowledge and address inequalities between different stakeholders. RED and RSPO fulfill this criterion on paper by seeking to prevent environmental burden shifting to third countries (European Commission 2009; RSPO 2019). An Indonesian NGO representative mentioned a "good traction, a good response from the [European] Parliament and Commission" to civil society demands to protect tropical forests, for instance (YP, interview 15 August 2018, Jakarta). The need to respect environmental and social requirements is specified in RED (European Commission 2009, art. 74). Moreover, RED requires that any joint programs ensures that renewable energy sources in third countries' energy consumption are not reduced as a result of EU's biomass importation (European Commission 2009, art. 38). After numerous criticisms, RSPO has also established a smallholder strategy for improving smallholder inclusion in the RSPO system (RSPO 2019).

At the same time, however, these efforts are compromised when the third criterion of citizenship is taken into account. Specifically, the biofuel governance arrangements implicitly reconstitute certain actors as inferior and others as superior. RED is an EU-led regulation, and RSPO is dominated by participants from the Global North, although palm oil is grown only in the Global South (European Commission 2009; Stattman et al. 2018). According to a local NGO representative, a common Indonesian reaction to such international standards is one saying "No, that's not really fit to our situation. Let's make our own standards!" (KSP, interview 20 August 2018, Bali).

This points to the limitations under the fourth criterion which refers to the creation of the conditions for citizenship. While the EU generally considers consequences for vulnerable groups in the Global South (mainly related to food security), only a dialogue and exchange of information is required (European Commission 2009). Similarly, although there are RSPO efforts to include more smallholders as mentioned above, this concerns mainly the stage of standard implementation (RSPO 2017). However, according to an Indonesian NGO representative, "in RSPO they try to include, to work with NGOs from the very first part - they're based on consensus" (KSP, interview, 20 August 2017). And yet, as Cheyns (2014) points out these efforts fail to include local minority voices by prioritizing a "liberal grammar" of individual interests over the common good and by emphasizing technical criteria detached from the real lives of people they affect. Hybrid governance arrangements in the biofuel sector thus demonstrate some efforts to create a political 
space as well as to level the playing ground, but the principle of citizenship is not yet fulfilled by both RED and RSPO.

\section{Compassion and palm oil certification for fuel purposes}

Besides citizenship, we also find traces of compassion in biofuel certification. First, regarding the depiction of humans and the environment, we find that biofuel certification is supposed to prevent compromising natural habitats and human wellbeing. Different from organic certification, palm oil certification for biofuel certification does not aim for an alternative to, but an improvement of conventional agricultural production. For instance, RSPO seeks to "improve the quality of life of oil palm farmers, create a more prosperous palm oil industry, and enable us to better conserve our planet and its resources" (RSPO 2018, p. 8). Second, biofuel certification is an explicit response to especially environmental problems related to their production. RED focuses on GHG savings from the use of biofuels and restricts the type of land on which biofuels can be grown, in order to prevent deforestation and loss of biodiversity (European Commission 2009; Kemper and Partzsch 2018). However, in comparison to organic, the certification standards for palm oil-based biofuel have attracted criticism over the years for lack of legitimacy, ambition and marginalization of local communities and smallholders (Cheyns 2014; Dauvergne 2018). According to an international NGO representative in Indonesia, helping poor farmers is not the first priority of companies, but joining RSPO is rather "about their reputation because they really care about the market" (SK, interview 21 August 2018, Bali).

Third, however, both RED and RSPO underline notions of non-fault. They acknowledge that biofuel production has negatively affected ecosystems and dependent communities (European Commission 2009; RSPO 2019). Additionally, fourth, the recent RSPO orientation towards smallholders suggests an acknowledgment that disadvantaged actors in the Global South deserve equal opportunities (RSPO 2017; VB, interview 28 August 2017). Moreover, a dedicated webpage on smallholder stories brings them closer to the public eye putting a human face on palm oil production, thus likely creating empathy towards them. It is yet unclear, however, whether the outcomes of such efforts will be adequate in generating compassion.

\section{Sufficiency and palm oil certification for fuel purposes}

Regarding the principle of sufficiency, first, RED and RSPO adopted criteria to prevent negative side-effects of biofuels, but they do not aim for a reduction of the overall fuel consumption and/or mobility. An European NGO representative summarized this aspect as follows: "Simply put, the renewable energy quota in the transport sector was an easy way out of broader challenges, (...) a different concept of mobility and not to basically take the level of fuel consumption that we have in Europe as a given" (SMK, interview 26 September 2017). There is no maximum threshold. To the contrary, RED and RSPO promote economic growth, including the growth of palm oil-based biodiesel (European Commission 2009; RSPO 2018, p. 8). Second, unlike Rapunzel $\mathrm{HIH}$, biofuel certification does not imply price guarantees or premiums for marginalized producers. RSPO incorporates social standards, such non-discrimination and minimum wages, which are also legally required in many producing countries (RSPO 2018). And RSPO's Smallholder Strategy explicitly targets marginalized economic actors. Recent efforts, for example to create long-term business relations between smallholders and buyers (RSPO 2017), can be seen as important steps in respect of the lower bound for the poor. However, neither RED nor RSPO do yet provide smallholders with any economic safeguards.

In sum, RED and RSPO only partly fulfil stewardship principles. In particular, in terms of citizenship, as standards come from the Global North, but are only implemented in the Global South, they reconstitute palm oil-exporting countries as inferior and importing countries as superior. In terms of compassion, however, there is a trend towards creating equal opportunities, especially, with recent orientations towards smallholders. Finally, the governance arrangement scores fairly poor regarding sufficiency. There is neither intention to define maximum thresholds, nor does biofuel certification imply price guarantees or premiums in respect of a lower bound for the poor.

\section{Discussion and conclusions}

With the global trend toward commodification, new hybrid arrangements have proliferated. This paper argued that stewardship can provide guidance for sustainability governance that, through its emphasis on citizenship, compassion and sufficiency, can simultaneously support environmental and social objectives. Using the example of palm oil, the paper examined the extent to which hybrid governance arrangements can enable stewardship.

Acknowledging that hybrid governance arrangements entail commodification, to what extent are they also capable of fostering stewardship? Both types of governance arrangements incorporate principles of citizenship, however, they differ clearly in interpretation (see Table 1). They demonstrate efforts of creating a global political space that reaches beyond the EU territory. The Organic Regulation is closely linked to IFOAM. When founding IFOAM, organic farmers moved from a personal to a political level of action. 
With the Organic Regulation, they accomplished a public standard that defines what can be labelled 'organic' in the EU. However, as noted earlier, although interests of third countries are taken into account, the political space of deliberation and co-decision is limited to EU boundaries. This is similar to EU RED. In both cases, then, it is primarily citizens in the Global North defining production standards addressing oil palms exclusively grown in countries of the Global South. Importantly, both schemes acknowledge and attempt to remedy this imbalance even if these efforts remain inadequate to date.

However, organic in combination with fair trade certification does a better job in acknowledging respective inequalities especially by providing price guarantees and premiums. It is then the hybridity of the governance arrangement that opens up the space for the creation of citizenship in the organic governance system. Nevertheless, as we argued earlier this is limited. Hybridity may open up the possibility for a global political space but falls short in creating the conditions necessary for political participation and voice on an equal basis especially in a North-South perspective. Especially with regards to biofuel governance, hybridity does not address questions of inequality necessary for citizenship even though attention to smallholders is a big step forward.

Further, while palm oil certification for both food and biofuel purposes is guided to some extent by compassion for other human beings, the concept of compassion is more explicitly expressed in the case of organic food certification. $\mathrm{HIH}$ aims to reform global agricultural and trade systems in order for them to become more reciprocal, starting with their own farming practices. Their vision for a healthier and more just world results from thoughts of seriousness and non-fault of those suffering. RED also tries to prevent harm against others by requesting minimum environmental and social standards for biofuels, but so far in a more limited manner.

We see most differences between the hybrid governance arrangements with regard to sufficiency. While organic food certification at least considers the limits of growth by prioritizing quality over quantity, palm oil certification for biofuel purposes is completely failing to apply the idea of sufficiency. EU citizens do not compromise their transport patterns at all. By contrast, biofuel certification allows them even to hold on to their lifestyle based on renewable instead of fossil sources.

What would it take to move to a stage of global stewardship, thus fostering both environmental sustainability and social justice, and what is the role of hybrid governance arrangements therein? What would it mean for certification programs to rightfully claim palm oil, marine or forest stewardship? Stewardship requires environmental and social standards which partly contradict the current mainstream. In particular, implementing ideas of compassion and sufficiency is not always convenient. Market actors following the stewardship principles, therefore, partly resist the dominant market structures that are based on notions of the "economic man" who is narrowly self-interested. Most obvious examples are price guarantees and fair trade premiums voluntarily paid by a particular range of consumers. Making such elements, which demonstrate respect for the lower bound for the poor, mandatory throughout certification systems, may provide a first step toward sufficiency and hence greater stewardship in hybrid governance.

However, relying on price mechanisms alone will remain insufficient. Stewardship requires the cultivation of a different ethic of production, consumption and relation with the human and non-human world. Such an ethic can be created by making space for critical conversation and emotional participation in public dialogue (see also Cheyns 2014). The latter is important because sustainability is not value free but invokes multiple contestations and tensions. The key for governance arrangements that aim to foster stewardship, then, is to make greater effort to reconcile the particular with the general, so that individual values, interests and emotions are expressed in relation to broader environmental sustainability and social justice concerns. Simultaneously, the general needs to be able to inspire the individual participation and commitment (see also Nussbaum 2015 on this point). For this purpose public dialogue in hybrid governance arrangements needs to relate to real peoples' lives, complexities and dilemmas beyond the technicalities of measuring progress towards sustainability.

Hybrid governance, then, can move beyond commodification, but this requires overcoming significant barriers. There are few or opposing incentives, but it is possible to exercise citizenship, compassion and sufficiency in the current market economy. However, it takes policy reforms to further a normative transformation of entire markets beyond ethical niches. A mandatory market share of certified products, as seen for "sustainable" biofuels ( $10 \%$ by 2020), for instance, could help the organic food sector to grow beyond the niche. In order to prevent the emergence of weak standards and leakage effects, that we can generally observe across sectors (Kalfagianni and Fuchs 2011; Wilson and Curnow 2013), under RED, the European Commission could approve only those certification schemes fostering principles of stewardship. Most importantly, both public and private actors and governance arrangements need to embrace stewardship as the basis for sustainability governance. That way, we may start witnessing a real transformation towards sustainability globally.

Acknowledgements Lena Partzsch's and Miriam Beulting's work was supported by the German Federal Ministry of Research and Education (Project No. 031B0235A). The authors would like to thank Harvey James and the anonymous reviewers for very helpful and encouraging feedback. Earlier manuscript versions were presented at the 2017 Lund Conference on Earth System Governance at Lund University, and the 2018 POLLEN Biennal Conference at Oslo Metropolitan University. A warm word of thanks also goes to all panel participants for the constructive discussions. 
Open Access This article is distributed under the terms of the Creative Commons Attribution 4.0 International License (http://creativeco mmons.org/licenses/by/4.0/), which permits unrestricted use, distribution, and reproduction in any medium, provided you give appropriate credit to the original author(s) and the source, provide a link to the Creative Commons license, and indicate if changes were made.

\section{References}

Alcott, B. 2008. The sufficiency strategy: Would rich-world frugality lower environmental impact? Ecological Economics 64 (4): 770-786.

Alkon, A.H., and J. Agyeman. 2011. Cultivating food justice. Race, class, and sustainability. Cambridge, MA: MIT Press.

Auld, G., and L.H. Gulbrandsen. 2010. Transparency in nonstate certification: Consequences for accountability and legitimacy. Global Environmental Politics 10 (3): 97-119.

Bäckstrand, K., J. Khan, A. Kronsell, and E. Lövbrand. 2010. Environmental politics and deliberative democracy. Examining the promise of new modes of governance. Cheltenham: Edward Elgar Publishing.

Barry, J. 1999. Rethinking green politics. London: Sage Publications.

Batson, D.C. 2011. Altruism in humans. Oxford: Oxford University Press.

Biermann, F. 2014. Earth system governance. World politics in the anthropocene. Cambridge, MA: The MIT Press.

Blühdorn, I. 2013. The governance of unsustainability: Ecology and democracy after the post-democratic turn. Environmental Politics 22 (1): 16-36.

Börse. 2018. Börse homepage. www.boerse-online.de/rohstoffe/palmo elpreis/euro. Accessed 4 June 2018.

Bourguignon, D. 2015. EU biofuels policy: Dealing with indirect land use change. www.europarl.europa.eu/RegData/etudes/ BRIE/2015/545726/EPRS_BRI(2015) 545726_REV1_EN.pdf. Accessed 9 Apr 2019.

Buzan, B. 2014. An introduction to the English School of International Relations: The societal approach. Cambridge: Polity.

Cassman, K., and A.J. Liska. 2007. Food and fuel for all: Realistic or foolish? Biofuels, Bioproducts and Biorefining 1 (1): 18-23.

Chapin, F.S., M.E. Power, S.T.A. Pickett, A. Freitag, J.A. Reynolds, R.B. Jackson, et al. 2011. Earth stewardship: science for action to sustain the human-earth system. Ecosphere 2 (8): 1-20.

Chen, S. and M. Ravallion. 2008. The developing world is poorer than we thought, but no less successful in the fight against poverty. Policy research working paper, vol. 4703. Washington, DC: The World Bank.

Chevriot, R. 1972. Creation of an international federation. https:// www.ifoam.bio/sites/default/files/page/files/founding_letter.pdf. Accessed 7 Apr 2019.

Cheyns, E. 2014. Making "minority voices" heard in transnational roundtables: The role of local NGOs in reintroducing justice and attachments. Agriculture and Human Values 31 (3): 439-453.

Chouliaraki, L. 2010. Post-humanitarianism: Humanitarian communication beyond a politics of pity. International Journal of Cultural Studies 13 (2): 107-126.

Chouliaraki, L. 2013. The ironic spectator. Solidarity in the age of post-humanitarianism. Cambridge: Polity Press.

Chryssavgis, J. 2007. Ecumenical Patriarch Bartholomew: Insights into an orthodox christian worldview. International Journal of Environmental Studies 64 (1): 9-18.

Daviron, B., and I. Vagneron. 2011. From commoditisation to de-commoditisation and back again: Discussing the role of sustainability standards for agricultural products. Development Policy Review 29: 91-113.
Dauvergne, P. 2018. The global politics of the business of "sustainable" palm oil. Global Environmental Politics 18 (2): 34-52.

Decety, J., and K.J. Yoder. 2016. Empathy and motivation for justice: Cognitive empathy and concern, but not emotional empathy, predict sensitivity to injustice for others. Social Neuroscience 11 (1): $1-14$.

Dings, J. 2016. Cars and trucks burn almost half of all palm oil used in Europe. https://www.transportenvironment.org/press/cars-andtrucks-burn-almost-half-all-palm-oil-used-europe. Accessed 7 Apr 2019.

Dobson, A. 2007. Environmental citizenship: Towards sustainable development. Sustainable Development 15 (5): 276-285.

Dobson, A., and D. Bell. 2006. Environmental citizenship. Cambridge, MA: MIT Press.

Dobson, A., and Á.V. Sáiz. 2005. Introduction. Environmental Politics 14 (2): $157-162$.

Eckersley, R. 2004. The green state. Rethinking democracy and sovereignty. Cambridge, MA: MIT Press.

Escobar, J.C., E.S. Lora, O.J. Venturini, E.E. Yáñez, E.F. Castillo, and O. Almazan. 2009. Biofuels: Environment, technology and food security. Renewable and Sustainable Energy Reviews 13 (6-7): 1275-1287.

European Commission. 2007. Council regulation (EC) No 834/2007 of 28 June 2007 on organic production and labelling of organic products. Brussels: European Commission.

European Commission. 2009. Directive 2009/28/EC of 23 April 2009 on the promotion of the use of energy from renewable sources and amending and subsequently repealing Directives 2001/77/EC and 2003/30/EC. Brussels: European Commission.

European Commission. 2014. Organic farming. A guide on support opportunities for organic producers in Europe. https://ec.europ a.eu/agriculture/organic/documents/eu-policy/european-actio n-plan/support-opportunities-guide_en.pdf. Accessed 9 Apr 2019.

Ewing, M., and S. Msangi. 2009. Biofuels production in developing countries: Assessing tradeoffs in welfare and food security. Environmental Science \& Policy 12 (4): 520-528.

Falkner, R. 2012. Global environmentalism and the greening of international society. International Affairs 88 (3): 503-522.

Falkner, R., and B. Buzan. 2019. The emergence of environmental stewardship as a primary institution of global international society. European Journal of International Relations 25 (1): 131-155.

Folke, C., R. Biggs, A.V. Norström, B. Reyers, and J. Rockström. 2016. Social-ecological resilience and biosphere-based sustainability science. Ecology and Society 21 (3): 41.

Fraser, N. 2000. Rethinking recognition. New Left Review 3: 107-120.

Fuchs, D. 2007. Business power in global governance. Boulder: Lynne Rienner.

Fuchs, D., A. Kalfagianni, and T. Havinga. 2011. Actors in private food governance: The legitimacy of retail standards and multistakeholder initiatives with civil society participation. Agriculture and Human Values 28 (3): 353-367.

Gómez-Baggethun, E., and R. Muradian. 2015. In markets we trust?: Setting the boundaries of market-based instruments in ecosystem services governance. Ecological Economics 117: 217-224.

Green, J.F. 2013. Rethinking private authority. Agents and entrepreneurs in global environmental governance. Princeton: Princeton University Press.

Gulbrandsen, L.H. 2014. Dynamic governance interactions: Evolutionary effects of state responses to non-state certification programs. Regulation \& Governance 18 (1): 74-92.

Gunderson, R. 2014. Problems with the defetishization thesis: Ethical consumerism, alternative food systems, and commodity fetishism. Agriculture and Human Values 31 (1): 109-117.

Guthman, J. 2007. The Polanyian way? Voluntary food labels as neoliberal governance. Antipode 39 (3): 456-478. 
Heindl, P., and P. Kanschik. 2016. Ecological sufficiency, individual liberties, and distributive justice: Implications for policy making. Ecological Economics 126: 42-50.

Higgins, V., J. Dibden, and C. Cocklin. 2015. Private agri-food governance and greenhouse gas abatement: Constructing a corporate carbon economy. Geoforum 66: 75-84.

IFOAM. 2012. Organic without boundaries. Celebrating 40 years, 1972-2012. http://orgprints.org/34243/1/ifoam40thanniv_extra ct_olc_web_0.pdf. Accessed 9 Apr 2019.

IFOAM. 2019. IFOAM Homepage. https://www.ifoam.bio/. Accessed 9 Apr 2019.

Jackson, T. 2009. Prosperity without growth. Economics for a finite planet. London: Earthscan.

Jaffee, D., and P. Howard. 2010. Corporate cooptation of organic and fair trade standards. Agriculture and Human Values 27: 387-399.

Kalfagianni, A., and D. Fuchs. 2011. Global gap. In Business regulation, non-state actors and development, ed. D. Reed, P. Utting, and M.-R. Ananya, 160-172. New York: Routledge.

Kemper, L., and L. Partzsch. 2018. A water sustainability framework for assessing biofuel certification schemes: Does European hybrid governance ensure sustainability of palm oil from Indonesia? Journal of Cleaner Production 192: 835-843.

Kopnina, H. 2017. Commodification of natural resources and forest ecosystem services: Examining implications for forest protection. Environmental Conservation 44 (1): 24-33.

Levidow, L. 2013. EU criteria for sustainable biofuels: Accounting for carbon, depoliticising plunder. Geoforum 44: 211-223.

Liodakis, G. 2010. Political economy, capitalism and sustainable development. Sustainability 2 (8): 2601-2616.

Lorek, S., and D. Fuchs. 2013. Strong sustainable consumption governance-Precondition for a degrowth path? Journal of Cleaner Production 38: 36-43.

Meyer, J. 2015. Engaging the everyday: Environmental social criticism and the resonance dilemma. Cambridge: MIT Press.

Moser, C., T. Hildebrandt, and R. Bailis. 2014. International sustainability standards and certification. In Sustainable development of biofuels in Latin America and the Caribbean, ed. B.D. Solomon and R. Bailis, 27-69. New York: Springer.

Muller, A., and M. Huppenbauer. 2016. Sufficiency, liberal societies and environmental policy in the face of planetary boundaries. GAIAEcological Perspectives for Science and Society 25 (2): 105-109.

Nussbaum, M.C. 2015. Political emotions. Why love matters for justice. Cambridge, MA: The Belknap Press of Harvard University Press.

O'Neill, J. 2001. Representing people, representing nature, representing the world. Environment and Planning C: Government and Policy 19 (4): 483-500.

Palmujoki, E. 2013. Fragmentation and diversification of climate change governance in international society. International Relations 27 (2): 180-201.

Parks, S. 2012. Divergent pathways of development: A comparative case study of human well-being in two Thai provinces. Environment and Planning C: Government and Policy 30 (5): 891-909.

Partzsch, L. 2011. The legitimacy of biofuel certification. Agriculture and Human Values 28 (3): 413-425.

Partzsch, L., M. Zander, and H. Robinson. 2019. Cotton certification in Sub-Saharan Africa: Promotion of environmental sustainability or greenwashing? Global Environmental Change 57: 101924.

Polanyi, K. 2001. The great transformation. The political and economic origins of our time. Boston, MA: Beacon Press.

Ponte, S., and C. Daugbjerg. 2015. Biofuel sustainability and the formation of transnational hybrid governance. Environmental Politics 24 (1): 96-114.

Potts, J., M. Lynch, A. Wilkings, G.A. Huppé, M. Cunningham, and V.A. Voora. 2014. The state of sustainability initiatives. Standards and the green economy. Winnipeg, MB: International Institute for
Sustainable Development, International Institute for Environment and Development, Canadian Electronic Library.

Princen, T. 2005. The logic of sufficiency. Cambridge, MA: MIT Press.

Rapunzel, L. 2014. Wir machen Bio aus Liebe. Von der Landkommune zur erfolgreichen Naturkostmarke. https://www.rapunzel.de/downl oad/40jahre-sonderheft.pdf.

Rapunzel, L. 2018. Rapunzel-Fairhandels-Programm. https://www.rapun zel.de/download/hih_kriterien_de_version5_sept2018.pdf. Accessed 9 Apr 2019.

Rapunzel. 2019. Rapunzel Homepage. https://www.rapunzel.de/. Accessed 9 Apr 2019.

Raynolds, L.T. 2012. Fair trade: Social regulation in global food markets. Journal of Rural Studies 28: 276-287.

Rockström, J., W. Steffen, K. Noone, Ă. Persson, F.S. Chapin III, E.F. Lambin, T.M. Lenton, M. Scheffer, C. Folke, H.J. Schellnhuber, B. Nykvist, C.A. de Wit, T. Hughes, S. van der Leeuw, H. Rodhe, S. Sörlin, P.K. Snyder, R. Costanza, U. Svedin, M. Falkenmark, L. Karlberg, R.W. Corell, V.J. Farby, J. Hansen, B. Walker, D. Liverman, K. Richardson, P. Crutzen, and J.A. Foley. 2009. A safe operating space for humanity. Nature 461: 472-475.

RSPO. 2017. RSPO smallholder strategy. https://rspo.org/smallholders/ rspo-smallholder-strategy. Accessed 9 Apr 2019.

RSPO. 2018. Principles and criteria for the production of sustainable palm oil. https://rspo.org/principles-and-criteria-review. Accessed 9 Apr 2019.

RSPO. 2019. RSPO homepage. http://www.rspo.org/about. Accessed 8 Apr 2019.

Rygiel, K. 2010. Globalizing citizenship. Vancouver: UBC Press.

Sachs, W., and T. Santarius. 2007. Fair future. Resource conflicts, security and global justice. London: Zed.

Schlosberg, D. 2004. Reconceiving environmental justice: Global movements and political theories. Environmental Politics 13 (3): $517-540$.

Setyowati, A., and C. Mcdermott. 2017. Commodifying legality? Who and what counts as legal in the Indonesian wood trade. Society \& Natural Resources 30 (6): 750-764.

Shedlock, M. 2016. Steen Jakobsen explains the rise of Trump "Social Contract is Broken." http://mishtalk.com/2016/03/16/steen-jakob sen-explains-the-rise-of-trump-social-contract-is-broken. Accessed 8 Apr 2019.

Smith, M. 1998. Ecologism: Towards ecological citizenship. Buckingham: Open University Press.

Squire, V. (ed.). 2010. The contested politics of mobility: Borderzones and irregularity. London: Routledge.

Stattman, S.L., A. Gupta, L. Partzsch, and P. Oosterveer. 2018. Toward sustainable biofuels in the European Union? Lessons from a decade of hybrid biofuel governance. Sustainability 10 (11): 1-17.

Steffen, W., Å. Persson, L. Deutsch, J. Zalasiewicz, M. Williams, C.C. Katherine Richardson, et al. 2011. The Anthropocene: From global change to planetary stewardship. Ambio 40 (7): 739-761.

United Nations General Assembly. 1987. Report of the world commission on environment and development: Our common future. Oslo, Norway: United Nations General Assembly.

Wilson, B.R., and J. Curnow. 2013. Solidarity ${ }^{\mathrm{TM}}$ : Student activism, affective labor, and the Fair Trade campaign in the United States. Antipode 45 (3): $565-583$.

Worldwatch Institute. 2018. Homepage. http://worldwatch.org/. Accessed 3 Aug 2018.

Young, I.M. 2004. Responsibility and global labor justice. Journal of Political Philosophy 12 (4): 365-388.

Zero Palmöl. 2018. Kosten von Palmöl. http://zeropalmoel.de/content/ kosten-von-palmöl. Accessed 4 June 2018.

Publisher's Note Springer Nature remains neutral with regard to jurisdictional claims in published maps and institutional affiliations. 
Agni Kalfagianni is Associate Professor of Transnational Sustainability Governance at the Copernicus Institute of Sustainable Development. She specializes in the development of rules and standards for sustainability by businesses and civil society organizations, and examines the effectiveness, legitimacy, and ethical considerations of private forms of governance.

Lena Partzsch is Professor of Environmental and Development Policy at the Institute of Environmental Social Sciences and Geography, University of Freiburg. Her research interests lie in the fields of sustainability governance and international relations.
Miriam Beulting is MSc student of Environmental Governance at the Institute of Environmental Social Sciences and Geography, University of Freiburg. 